\title{
Young Ichthyologist Award 2009 and Best Article Award 2009
}

Published online: 15 October 2009

(C) The Ichthyological Society of Japan 2009

The Ichthyological Society of Japan (ISJ) presented the Young Ichthyologist Award 2009 to Dr. Kohji Mabuchi (Ocean Research Institute, The University of Tokyo) for his outstanding research activities and papers on ecology, taxonomy, and molecular phylogeny of marine and freshwater fishes. The following two papers were selected for the Best Article Award 2009.

Kimura S, Kimura R, Ikejima K (2008) Revision of the genus Nuchequula with descriptions of the three new species (Perciformes: Leiognathidae). Ichthyological Research 55(1):22-42

Fujita T, Nishino M, Hosoya K (2008) The original scenery of the "Naiko" lagoons around Lake Biwa inferred by fish specimen survey. Japanese Journal of Ichthyology 55(2):77-93

Dr. Kohji Mabuchi gave a commemorative lecture entitled "New perspectives on the history of East Asian fish fauna based on molecular phylogenetic analyses: lessons from the studies of the labrid genus Pseudolabrus and native Japanese common carp" on 11 October 2009 during the ISJ annual meeting in Shinagawa, Tokyo. He and the authors of the Best Article Award 2009 papers (Dr. Seishi Kimura of Mie University and Dr. Tomohiko Fujita of Civil Engineering \& Eco-Technology Consultants, Co., Ltd.) received the commemorative certificates of merit from the ISJ President, Dr. Mutsumi Nishida. 